\title{
REPOSITIONING INDUSTRIAL PSYCHOLOGY FOR THE CREATION OF NEW FUTURES IN TURBULENT TIMES
}

\author{
KP MOALUSI \\ Department of Industrial Psychology \\ UNISA \\ (Formerly from the University of the North)
}

\begin{abstract}
It is argued that the current management paradigm has an obsession with financial statements and comparisons, or cost reduction, no matter what the price is in long term organisational and societal terms. The author does not suggest that the bottom line is unimportant, rather that we need to look beyond that. The challenge is to seek knowledge that will assist in addressing the issues that are pertinent to the South African workplace without being oblivious to the bottom line. Improperly framed questions will not elevate the discipline and the profession from a marginal to a strategic role, at least not in organisational settings. The author asserts that Industrial Psychology has a great deal to offer managers regarding what the thrust should be in the creation of new futures in turbulent times. This would require focussing on relevant issues rooted in the workplace.
\end{abstract}

\section{OPSOMMING}

Die artikel berus op die argument dat die huidige bestuursparadigma plaas ' $n$ oordrewe klem op finansiële state en vergelykings, of koste-verlaging, ongeag die lang termyn organisatoriese en sosiale prys wat betaal word. Die skrywer stel geensins voor dat finansiële prestasie onbelangrik is nie, eerder dat verder as hierdie prestasie gekyk moet word. Die uitdaging is om kennis te skep wat tersaaklike kwessies in die Suid-Afrikaanse werkplek sal aanspreek sonder om finansiële prestasie te onderbeklemtoon. Onbehoorlik geformuleerde vrae sal die dissipline en professie nie vanaf die kantlyn na 'n strategiese rol verskuif nie, ten minste nie in 'n organisatoriese opset nie. Daar word geredeneer dat die Bedryfsielkunde 'n groter bydrae kan maak aan bestuurders t.o.v. wat beklemtoon behoort te word in die skep van nuwe toekomstige moontlikhede tydens dinamies veranderende tye. Hierdie bydrae vereis egter 'n fokus op toepaslike kwessies in die werkplek.

Modern business organisations exist in an environment characterised by unrelenting global competition and change. This means that organisations need to continuously redefine and reposition themselves to deal with unexpected changes in their environment. As a result organisations have to continually implement changes in structure, strategy, process, and culture (Armenakis, Harris and Mossholder, 1993).

Organisational change may be triggered by a variety of factors (Hall, 1991). It is often because of the need to survive and remain competitive that organisations embrace change. However, as Hall (1991, p.182) notes:"At times, change is virtually forced on an unwilling organisation, while at other times, change is openly embraced and sought." Change in an organisation may be incremental (also called first order or tactical change) or discontinuous (also called second order or strategic change). The type of change also depends on whether an organisation is tightly or loosely coupled (Spender and Grinyer, 1995).

The challenges for survival and competitiveness are more pressing for organisations in industries characterised by discontinuous change or operating in hyperturbulent environments (Meyer, Goes and Brooks, 1993). Under these circumstances change calls for a complete re-think of how we learn and do things (Handy, 1989). Organisations operating under such environments will have to endure and become competitive in order to survive and thrive.

In South Africa the dismantling of statutory discrimination, the introduction of new labour laws, the re-admission of business South Africa into the global economy, and the opening up of its markets to global competition have altered the workplace fundamentally and created more complex organisations. These changes have created unprecedented pressures and challenges for corporate South Africa. Some of these organisations have been unable to successfully grapple with these changes.

The problem originates from organisations' obsession with financial results and the domination of decisions by financial managers "who agonise over financial statements and comparisons rather than looking at the real trends and competitive forces in the market" (Bloch and Groth, 1998, p. 3). This makes the maximisation of the Requests for copies should be addressed to: KP Moalusi, Department of Industrial Psychology, UNISA, PO Box 392, UNISA, 0003 bottom line the superordinate goal, in this way encouraging organisations to make decisions based on short term benefits.

During periods of turbulence and change organisations search for ways of improving performance and competitiveness in order to create organisations of the "future". An organisation's competitive advantage is defined in terms of its resources. Although all resources are important for organisational performance and competitiveness, human resources are regarded as vital and critical for sustaining an organisation's competitive advantage because knowledge, be it of customer needs or markets; forms of industrial and social relations; human resources management; strategy; products; or innovation embedded in people. As Von Krogh and Roos (1996, p.32) state, "knowledge is the most important source of creating and sustaining competitive advantage." A significant amount of environmental turbulence and organisational response to change has impacted adversely on the human side of organisations. This is in spite of the commonly espoused theory that our most valuable assets are our human resources.

This article, firstly, offers an explanation of organisations' obsession with cost reduction and presents the argument that focusing largely on cost reduction may not help long term organisational effectiveness. Organisations'response to the forces of globalisation and competition has imposed social and economic hardships on people and organisations in the form of costs to employee health, the family, society and organisational performance. Restructuring, and more specifically downsizing, will be the focal point of the discussion because it is one of the common reorganisation strategies aimed at improving the bottom line. But downsizing in most instances does not assist long term organisational performance partly because of inadequate planning and implementation that result in deleterious effects on the victims and survivors alike (Sadri, 1996; Appelbaum, Henson, and Knee, 1999; Appelbaum, Close and Klasa, 1999; Appelbaum, Everard and Hung, 1999).

However, some measure of success has also been reported for well planned and implemented downsizing programmes (Cameron, Freeman and Mishra, 1993; Baruch and Hind, 1999).

Organisations that use downsizing without a well thought out plan 
are often reacting to short term financial pressures and comparisons that may address short term outcomes. This may lead to incongruity between the espoused theory that employees are the organisation's most critical assets and the theory-in-use which reflects the contrary.

Secondly, the argument is offered in the article that the above dynamic helps in explaining the marginal role of Industrial Psychology and Industrial Psychologists in strategic issues in organisational settings. This may either be due to the tolerance for framing improper questions or a lack of awareness of the real issues rooted in the South African workplace. These two plausible explanations marginalise the discipline, and Industrial Psychologists, in the creation of contexts that persuade organisations to challenge their existing modes of working and thinking. Without relinquishing the theoretical and broad base of the discipline, we need to pay attention to the genuine issues pertinent to the South African workplace. As a discipline geared towards the understanding and enhancement of the workplace from a psychosocial perspective, Industrial Psychology has a great deal to offer managers in terms of what the thrust should be in the creation of new futures during turbulent times.

\section{AN OBSESSION WITH SHORT TERMISM AND THE BOTTOM LINE}

Although restructuring includes multiple forms of change, for example portfolio, financial and organisational restructuring, it has often meant downsizing for many organisations. Employees, especially at the shop floor, and lower management levels usually are adversely affected. Downsizing is a systematic reduction of an organisation's workforce through an intentionally instituted set of activities and actions by which an organisation aims to improve its efficiency, effectiveness and overall performance (Cameron, et al., 1993).

Looking at the current environmental turbulence, and the manner in which some organisations are responding to it, it is clear that they are unable to devise creative long term solutions to deal with the situation. As if downsizing is the panacea for all maladies besetting organisations, downsizing is often uncritically embraced. Downsizing often does not always result in an overall improvement in organisational performance, especially in organisations that implement it haphazardly or poorly. Under these conditions, it becomes a vicious cycle that attempts to remedy previous downsizing projects (Appelbaum, et al., 1999). The main reason for this is lack of a clear vision or a blueprint for the future and a focus on short term benefits.

Some of the primary problems with downsizing are increased job insecurity and increased stress from increased workloads (Sadri, 1996). Closely related to these effects, is the impact of the dramatic changes in the world of work that have created what Cooper (1999) refers to as an intrinsically job insecure and less stable work environment that is partly responsible for certain industrial and social problems. Managers very often lack the competencies to deal with the new complexities; long working hours, outsourcing and downsizing may adversely affect loyalty, morale, motivation, employees' health, family life and perceptions of job security; and ultimately the positive bottom line that organisations are striving for. Whilst it is important to work to improve the bottom line, it is also important to do so in order to improve employees' willingness and readiness.

Under these conditions commitment to management practices that place employees at the centre of organisational performance is offset by placing an emphasis on short term benefits to such an extent that the importance of employees tend to become more of a rhetoric than a reality. This can partly be explained by the dominance in management of people from highly technical areas such as engineering, law and finance. At times such people have little knowhow, time, interests or awareness of complex organisational issues.
It is this inability to read the complexity of organisations that often persuade them to focus on short term quick fixes (Hucyzynski, 1993, quoted in Mamman and Saffu, 1998).

In reviewing literature on Western management failures, Mamman and Saffu (1998) note that short termism, top management and entrepreneurs' greed is partly to blame for the quick fixes in attempting to solve dynamic and complex organisational problems.

One would assume that given its belief in the centrality of people in organisational performance and the overall thrust of organisational development, Industrial Psychology would be more influential in attempts to long term sustainable organisational competitiveness. Industrial Psychology graduates and professionals both as employees, consultants and managers should shoulder their fair share of the blame. But the behaviour of managers may not be properly understood outside the following context within which they are operating (Mamman and Saffu, 1998):

- managers, like their subordinates, are operating within organisations that have political and economic power over them which has an influence over their actions.

- environmental uncertainty and organisational objectives encourage organisations to institute rules, regulations, procedures and structures that will ensure control as a means of managing uncertainty and monitoring objectives.

- competition and financial pressures force managers to focus on short term outcomes.

- shareholders, fund managers and the stock market pressurise managers to pursue corporate missions that emphasise the creation of wealth that necessarily lead to an emphasis on short term benefits.

- the nature of business, and its environment, drive managers to go after short term goals.

The preceding points may reveal the reasons for the minimal impact of Industrial Psychology and Industrial Psychologists on managerial actions, and the need to be conscious of the context within which managers are operating. More importantly, it demonstrates the need to develop programmes that will be critical of how and why things are done so that the discipline and profession can improve its understanding of management. Constructive criticism would not only help in enhancing our understanding of management, but also should improve the current management practice and the theory of how managers behave and business organisations are run (Mamman and Saffu, 1998).

The launching pad for balancing reality and the ideal is the context: address issues pertinent to the workplace without being oblivious to the broad base of the discipline. However, this does not provide an explanation of the South African workplace because little or no information on the topic is available in the public domain. Most of the information may be contract work by consultants or specific organisations, and therefore not easily accessible to the public.

South Africa's capital markets; organisations' preference for increased volume of sales and market share; shareholders and fund managers' pressures on organisations to perform; the dominance of corporate South Africa by technically trained managers; and continued employment for employees may provide some leads to the understanding of South African management. This would in turn facilitate the process of identifying what the thrust of Industrial Psychology should be.

Framing appropriate questions to address the issues rooted in South African workplaces

Bryans (1999) correctly observes that a university should respond positively to the needs articulated by the community. It should make a contribution to its locality, and ultimately to the creation of a better society. The thrust of the discipline and profession of Industrial Psychology places it in a more ideal position to contribute to the understanding and enhancement of the work place from a psychosocial perspective. Paying attention to the issues pertinent to 
the South African workplace will facilitate the much needed balance between theory and practice, between ideal and reality.

The dramatic changes in the world of work demand that managers are prepared to deal with new, complex challenges because these challenges are an inherent part of the workplace in South Africa, and pose formidable impediments to competitiveness. The radical way the world of work is changing will continue unabated. In this decade we are likely to witness an intensification and acceleration of change. Trends regarding the influence of capital markets; the changing contract of employment; reorganisation; the outsourcing of activities that do not form part of the core business of organisations; downsizing; mergers and acquisitions; and strategic alliances or partnerships will become the established way of doing business.

Each of these trends has the potential to impact negatively on the individual and the organisation. For example, how do capital market fluctuations impact on the behaviour of organisations? How does the changing contract of employment affect employee loyalty and how can organisations build loyalty under these conditions? What are the implications of blending two totally distinct organisations with different strategies, products or services and cultures? In a period of mergers, acquisitions and partnerships, how do organisations ensure that these new modes of competing become successful?

Capital markets, the new contract of employment, and the emergence of strategic alliances and partnerships can be used as examples to illustrate the significance of relating the discipline and profession of Industrial Psychology to the everyday reality of organisations.

\section{Capital markets and management behaviour}

Capital markets put pressure on the management of organisations to maximise the return to shareholders. Hence for these managers price-earnings ratios and cash flow statements matter most. Moreover, these managers are kept on their toes by potential hostile take-overs. As a result the preoccupation with producing good to outstanding financial returns become the order of the day. South Africa has well-developed financial and capital markets. This has the implication that financial information about the activities of a firm is readily available. Therefore, shareholders are able to exercise a strong surveillance of the activities of firms. Cost reduction becomes a prime consideration to managers under these circumstances. Variable factors of production, in particular, labour, are the first targets in the event of organisations not performing particularly well.

Dividend policy also affects the behaviour of management with regard to financial statements. The declaration of dividends is quite important to potential investors since a firm that fails to declare dividends may be viewed as being in financial problems. Therefore the declaration of dividends can be regarded as a stimulus to future investment.

Tax policy affects the behaviour of organisations from a cost perspective. At the moment South African company tax stands at $35 \%$ and the tax on dividends is $12,5 \%$ (A B D \& T, 2000). This low tax on dividends has the effect that companies can readily declare dividends. When firms declare dividends, their retained profits are minimised. This means that they have fewer funds for expansion and the creation of employment opportunities.

\section{A new contract of employment}

The new contract of employment emphasises the bottom line. This has in many respects created intrinsic job insecurity and a lower sense of loyalty to organisations (Cooper, 1999) because a desirable bottom line results in short term thinking and actions. As Bloch and Groth (1998, p.5) observe, "managers who have no more than a five-year contract, think and plan differently than entrepreneurs who have run their own concern for a decade and have at least one more ahead of them. Only then, is optimal, longrange planning possible and quick profits are unnecessary; they can be sacrificed in order to secure the longer-term survival of the company. On the other hand the manager with a five-year time span to prove him/herself tends to take risks and gamble in order to secure quick, impressive gains, because that will inevitably be the performance measure, not endurance and consistency". This is not a simplistic explanation of the complexity of the strategic decision making process explained by amongst others Strickland and Thompson (1980). The author is not oblivious to the fact that the nature of business determines the need and effectiveness of either short term or long-range planning horizon.

It is this and similar situations that lead to short termism and complicate employees' and managers' lives because of the pressures they impose. Cooper (1999) notes the pressures of rising expectations imposed by the new contract of employment. These pressures, combined with fear of failure and job loss, result in higher levels of stress for managers or employees with such contracts. However, as Bloch and Groth (1998) observe not all managers suffer from the fear of failure. The same contract of employment may provide managers, who are removed from office before the end of their contract, with severance payment. Some managers, whose companies incur massive financial losses that result in shareholders not receiving dividends, often receive substantial payments.

The emergence of strategic alliances and partnerships The third example focuses on the high prevalence of forming strategic alliances and partnerships. The proliferation of these relationships should encourage Industrial Psychology to treat them as a focus area. In a highly competitive business environment, organisations have to continuously reinvent themselves (Goss, Pascale and Athos, 1993; Martin, 1993). Organisations strive to improve the services they render, design products of a superior quality, increase their market share, and speed up new product development (Slater, 1995). They are continuously searching for competencies that will accelerate flexibility, agility and speed. Strategic alliances and partnerships very often provide organisations with such competencies.

It has already been alluded to that the qualities of flexibility, agility and speed reside in people. The belief that people are the critical asset that can either make or break an organisation, as well as the fact that people's willingness and readiness to contribute is one of the domains of Industrial Psychology, makes it necessary to pay attention to people's role in the enhanced competitiveness sought through strategic alliances and partnerships.

Industrial Psychology as a discipline that is geared towards understanding and enhancement of the workplace from a psychosocial perspective, could play a meaningful role that may augment what other disciplines cannot. The discipline and profession need to understand the complexities inherent in strategic alliances and partnerships from a people's perspective. Managers from technical areas such as engineering, law or finance may not be able to deal adequately with these issues because they lack the expertise, understanding and awareness of their people complexity. This is not to exaggerate the actual or potential contribution Industrial Psychology and Industrial Psychologists can make. It is only to say that a sound knowledge of Organisational Behaviour, Organisational Theory, Organisational Development and Strategic Human Resource Management may serve as a basis for understanding the complexities inherent in organisations using strategic alliances and partnerships as a competitive strategy.

The three issues discussed above are but examples of a plethora of issues that are prevalent in the South African workplace, and in which Industrial Psychologists and graduates could play a meaningful role. Some further issues that deserve attention because they impact on employees, the bottom line and society, are:

- management's competency to deal with dynamic and complex organisational issues;

- management greed and a lack of morality;

- corruption and fraud which drains the bottom line and is a 
deterrent for potential investors;

- evaluating the effectiveness or ineffectiveness of new concepts and ideas in management practice that managers are quicker to latch on to because they are Western in origin; and

- the reluctance to experiment with non-Western management ideas and concepts even when they appear to hold potential.

\section{WHAT SHOULD THE THRUST OF INDUSTRIAL PSYCHOLOGY BE?}

As a discipline geared towards the enhancement of the workplace from a psychosocial perspective, Industrial Psychology remains marginal in influencing crucial and strategic decisions in organisations because line managers have the prerogative to make decisions relating to the bottom line. What are plausible reasons for this state of affairs and what should the future look like?

Without being prescriptive, the following issues may help in rekindling or rejuvenating the centrality of Industrial Psychology in managerial decision making:

A re-emphasised focus on the human side of organisations The cutting edge of Industrial Psychology remains its strong focus on the human side of organisations. This makes it imperative for the discipline to encourage management to challenge their existing modes of working with and thinking about people. Current human resource trends bring into question the effective integration of Industrial Psychology (particularly, Human Resource Management) into our organisations at a strategic level. A lack of empirical data on the South African workplace may prevent one from confidently asserting that Industrial Psychology (or Human Resource Management) remains at the periphery of organisational strategy and has not gained centre stage in everyday management vocabulary.

One suspects, however, that the incongruity between the espoused theory that employees are the key to sustainable competitive edge, and the theory-in-use that reveals that organisations do not effectively address the issues that impact on employees' well-being, may serve as evidence for the marginal role of Industrial Psychology in organisational settings.

Although it is incumbent upon employers to reflect, as Cooper (1999) says, on where they are going and what that may mean for employees and society, and try to action their espoused but seldom implemented belief that our most valuable assets are our human resources, Industrial Psychology/Psychologists need to reflect on how they contribute to the current state of affairs. Constructive criticism of the ruling management paradigm should form the starting point of such criticism.

\section{Adopting an interdisciplinary approach}

As Industrial Psychology enters into a new millennium, questions about the ability of Industrial Psychologists to deal with the issues raised in this article, or to comprehend them and enable managers to deal with, them are important. If these are the realities of the new world of work, how can Industrial Psychologists impact on the organisations in a desired manner? These questions should guide curricula and the teaching of Industrial Psychology in the new dispensation. Courses in Business Management and Economics, the use of case studies and study of pressing business issues are important considerations in this instance.

Closing the gap between theory and practice

The gap between theory and practice, ideal and reality, can be bridged by among others dealing with issues that are pertinent to the South African workplace. Partnerships with the private and public sectors can facilitate the creation of such bridges between these disparate contexts.

Critiquing organisations' management paradigms
Industrial Psychologists must encourage the creation of conditions that will persuade organisations to challenge their existing modes of thinking and working. But in doing so, one needs to take into account or incorporate the context within which managers are operating. Such criticisms will not only help in improving management practices, but also in developing a viable theory that can enhance our understanding of how organisations function in reality (Mamman and Saffu, 1998).

Training programmes to enhance the visibility of Industrial Psychology

Based on the challenges faced by managers, now and in the future, training programmes can be designed that take into account the complexity and interplay between various organisational issues. Short term training programmes that aim at helping managers to deal with the complexity of the new world of work, may also be beneficial. Currently, business schools, Business Management, and consultants are dominating the space. Such initiatives will enhance the relevance and visibility of Industrial Psychology.

\section{CONCLUSION}

This article has not provided a panacea to the problems that beset the workplace, but attempted to highlight some of the areas that need urgent attention from Industrial Psychology in order to improve the state of the workplace. Industrial Psychology as a discipline and profession is faced by a new dispensation with too little visible presence in organisational settings, particularly when it comes to strategic issues. The fate or destiny of the discipline and profession may become precarious if it fails to address pressing issues rooted in the South African workplace. It will remain to be a lucrative profession for fewer registered people but be marginal or irrelevant to the strategic direction of many organisations. One may see more of other professional people employed in roles that one would assume are suitable for Industrial Psychologists. Therefore the challenge is to reposition Industrial Psychology to create new futures during turbulent times.

\section{REFERENCES}

A B D \& T Chartered Accountants (S.A.) (2000). Tax guide 2000-2001. South Africa.

Appelbaum, S.H. Close, T.G. \& Klasa, S. (1999). Downsizing: An examination of some success and morefailures. MCBManagement Decision, 37(5), 1-17.

Appelbaum, S.H. Everard, A. \& Hung, L.T.S. (1999). Strategic downsizing: Critical success factors. MCB Management Decision, 37(7), 1-24.

Appelbaum, S.H., Henson, D. \& Knee, K. (1999). Downsizing failures: an examination of convergence/reorientation and antecedents - processes - outcomes. MCB Management Decision, 37(6), $1-22$.

Armenakis, A.A., Harris, S.G. \& Mossholder, K.W. (1993). Creating readiness for organisational change. Human Relations, 46(6), 681-703.

Baruch, Y. \& Hind, P. (1999). "Survivor syndrome" - a management myth? MCB Journal of Managerial Psychology, 15(1), 1-10.

Bloch, B. \& Groth, K.J. (1998). German managerial failure: the other side of the globalisation dilemma. MCB European Business Review, 98(6), 1-14.

Bryans, P. (1999). Partnership in practice: what can be learned? MCB Industrial and Commercial Training, 31(7), 1-6.

Cameron, K.S., Freeman, S.J. \& Mishra, A.K. (1993). Downsizing and redesigning organisations. In G.P. Huber \& W.H. Glick (Eds.) Organisational change and redesign: Ideas and insights for improving performance. New York: Oxford University Press.

Cooper, C.L. (1999). Can we live with the changing nature of work? MCB Journal of Managerial Psychology, 14(7/8), 1-3.

Goss, T., Pascale, R. \& Athos, A. (1993). Risking the present for a powerful future. Harvard Business Review, 71(6), 97-108.

Hall, R.H. (1991). Organisations: Structures, processes, and outcomes. 
New Jersey: Prentice Hall.

Hamel, G. \& Prahalad, C.K. (1989). Strategic intent. Harvard Business Review, 67(3), 63-76.

Handy, C. (1989). The age of unreason. London: Arrow Books.

Mamman, A. \& Saffu, K. (1998). Short termism, control, quick-fix and bottom line: Towards explaining the Western approach to management. MCB Journal of Managerial Psychology, 13(5/6), 1-16.

Martin, R. (1993). Changing the mind of the corporation. Harvard Business Review, November-December, 81-94.

Meyer, A.D. Goes, J.B. \& Brooks, G.R. (1993). Organisations reacting to hyperturbulence. In G.P. Huber \& W.H. Glick (Eds.) Organisational change and redesign: Ideas and insights for improving performance. New York: Oxford University Press.

Pucik, V. (1998). Strategic alliances, organisational learning and competitive advantage: The HRM agenda. Human Resource Management, 27(1), 77-93.

Sadri, G. (1996). Reflections: The impact of downsizing on survivors - some findings and recommendations. MCB Journal of Managerial Psychology, 11(4), 1-3.

Slater, S.F. (1995). Learning to change. Business Horizons, NovemberDecember, 13-20.

Strickland, Jr. A.A. \& Thompson III A.J. (1980). Strategy formulation and implementation: Tasks of the general manager. Texas: Business Publications, Inc.

Von Krogh, G. \& Roos, J. (eds.) (1996). Managing knowledge: Perspective on co-operation and competition. London: Sage Publications. 